\title{
GROWING URBAN GREEN MOVEMENT: EVALUATE THE REINFORCEMENT OF COMMUNITY GARDEN FOR RENEWAL COMMUNITY
}

\author{
SUVIMALI.E.A.S.S. ${ }^{1} \&$ HERATH.M. ${ }^{2}$ \\ 1, 2 Department of Town \& Country Planning, University of Moratuwa, Katubedda, Sri Lanka \\ 1indunilwijeskara@gmail.com, 22malani@uom.lk
}

\begin{abstract}
As per the United Nations' 17 Sustainable Development Goals (SDGs) "Sustainable cities \& Communities" is vital for the healthy planet by 2030 . Because nontackle population growth at city level causing to deforestation and it is outstripping for unsustainable cities as such for better livability. Since, 1990s, the decrement of non-built-up areas due to rapid urbanization directly cause for interrupting socio- ecological interaction \& social ties among community in Sri Lanka. Recently, there is an emerging tendency on continuing community based agricultural sites as a social space for community gathering and interacting with variety of active physical activities as well to increase the urban fabric. The aim of the research is to investigate reinforcement of community garden for renewal community by studying diverse social and physical factors, evaluating functioning community garden in Colombo. The methodology of the study was comprised with onsite observations and in-depth interview and the data were qualitatively analyzed by using NVvio software. Accordingly derived 15 different social and 9 different physical factors from the community perceptions. Particularly, respondents having a desire to create a village and sense of place within the urban setting as SDGs rely.
\end{abstract}

Keywords: Community Garden, Community renewal, Social interaction, Community involvement

\section{Introduction}

In developing countries, the revolution of urbanization deteriorates the sustainability and livability of cities (Rondineli, 1990). The density of urban built-up areas increments and urban sprawl (Kovács, 2009) is negatively threat to decreases of urban greenery spaces, thus the places for community interactions decreases as well (Nagy, 2017). Hence, sustainable land use is critical importance to balance socioecological interaction of the growing population (Wilson, 2007). In that case, Mougeot in 1994 suggested that community garden as a tool for sustainable urban development and land use planning. Meanwhile, community gardens have identified as an innovative method of renewal city community while enhancing community interaction and community involvement (Landman, 1993). This low-cost, low-tech urban renewal strategy is releasing intangibles like beauty, sense of place and neighborhood security as well tangibles like foods" (Hynes, 1996). In further, community garden has become increasingly important component of sustainable community development strategies (LEWIS, 2009) because, it leads to strength the neighborhoods connectivity in urban areas by fostering community ties and interaction, neighborhood pride, community involvement and feelings of safety (Krasny, 2004). However, urban community gardens are bringing life and livability, seed by seed, back to their neighborhoods and nourish body, and also the soul (GOSA, 2006) because it supports to upgrade neighborhood quality" (Glover, 2004).

As a developing nation, Sri Lankan cities have been expanded rapidly since 1990s due to urbanization especially in Colombo district. Because of this higher level of urban expansion Colombo non built-up areas decreased from $125 \mathrm{Km}^{2}$ in 1995 to $10 \mathrm{Km}^{2}$ in 2017 (Anon., 2017). Moreover, urban green spaces including urban agricultural lands in Colombo city has decreased from $31.0 \mathrm{~km}^{2}$ in 1980 to $5.02 \mathrm{~km}^{2}$ in 2015 and the per capita green space value recorded in 2015 as $7.16 \mathrm{~m}^{2}$ which is below than WHO 
standard of $9 \mathrm{~m}^{2}$. The greenery space change in Colombo is remarkable since 2001, and annual reduction rate recorded as $0.46 \mathrm{~km}^{2}$ between $1980-1988,0.39 \mathrm{~km}^{2}$ between $1988-1997,0.37 \mathrm{~km}^{2}$ between $1997-2001$, $1.37 \mathrm{~km}^{2}$ between $2001-2011$ and $0.71 \mathrm{~km}^{2}$ between $2011-2015$ due to conversion of vacant areas and forest areas into urban settlements, administration buildings and industrialized parks (PUSSELLA, 2017). Moreover, paying attention to the home garden in highly populated wet zone in Sri Lanka, it has a considerable degradation in past two decades due to urbanization (Dela, 2011). In western province, Colombo has the lowest percentage of home garden cover and it is $13.1 \%$, particularly, Gampaha has $25.2 \%$ and Kaluthara has $20.1 \%$. However, as this way the reduction of green space in Colombo city due to urbanization (PUSSELLA, 2017) directly affect to the decrease of places where people can integrate as socio-ecological way and eventually discontinuity of community interactions and involvement as well. Furthermore, the Colombo Master Plan in 2008 discloses that there are 66,000 households in 1,506 pockets within Colombo living in settlements which are unfit for human habitation (Samaratunga, 2013) because they do not have enough recreational and shared space to create community feeling $\left(O^{\prime}\right.$ Hare, 2013) with the issue of non-buildup land filling. But in the context scholars has mentioned that, community gardens as the tangible arenas urban residents can induce and sustain relationships with the elements of nature, and with their neighborhood as well (NURSEY-BRAY, 2014). Moreover, in present, nearly $25 \%$ of the Sri Lankan population living in urban areas and expected, that much will increase up to $65 \%$ by 2030 (Susantha Amarawickrama, P Singhapathirana , 2015). This population increment manipulates the urban decay with the destruction of socio- ecological interaction among community. However, according to the Melissa N. Poulsen in 2014, community garden is a main factor of the urban landscape. It is accomplishing a safer refuge for urban environment while beautifying urban space, improving sense of security, enhancing neighborhood connection and changing food environment so on.

Accordingly, previous explained, most of the developed countries already practicing community garden concept for develop community involvement and community interaction against to the socioecological interruption while getting vast range of social benefits. As well, developing countries also had been spontaneously adopted this concept to address decrement of socio-ecological interaction of community and uplift well- being of city dwellers by improving more sustainable growth at community levels (Orsini, 2013). Sri Lanka also a developing country and has a need for enhance the community interaction and community involvement among community which occur with the issue of green spaces reduction in cities where people can get together. Hence, the research is questioning the reinforcement of community garden for buildup community interaction and community involvement. In case, investigate the different social and physical factors which influence to motivate community to community garden through analyzing community perceptions. The study area is Papiliyana Siriparakum Koratuwa community garden in Kesbewa DSD of Colombo district in Sri Lanka. There has not been research investigation completed yet to address this knowledge gap. This study is following the qualitative approach by incorporating with social capital theory and place making theory. Eventually, by elaborating the investigated diverse social and physical factors under different themes, the study will assess the reinforcement of community garden to renewal community. However, this research is focus on the aspects of theories, field work as well suggestions of the literatures and because of that can be happen some limitations. As same as the research is totally based on the community perceptions and it can be leading a bias reporting with qualitative interpretations.

\section{Literature Review}

\subsection{COMMUNITY GARDEN (CG)}

Community garden is a small yard which usually less than one hectare and managed by a community group for the purpose of growing foods (Crabtree, 1999). Although historically, community gardens considered as a way of improve local food supplies, contemporary it focuses to create opportunities for community building (Armstrong, 2000), enhance civic participation (Glover, 2004) and community interactions. In the history, CGs appear with the changes of economic and social crises (Bassett, 1979). However, this urban green movement has evolved on the historical ground in USA and Western Europe in late $19^{\text {th }}$ century and periodically, the appearance of community garden was emerged based on different reasons. After 2008 the need of creating community garden was community renewal. This concept is a grass roots initiative to create catalysts for neighborhood improvement ((Linn, 1999) and to establish and sustain relationships with their neighborhood (Kurtz, 2001). Moreover, community gardens stimulate safer spaces, where neighbors can gather (Winch, 2014), interact and foster community involvement (Krasny, 2004). More recently, community gardens have integrated with the sustainable community development strategies of Earth summit in 1992, because which manipulates community participation and community interactions to bring solutions for local problems (Winner, 2007). 


\subsection{COMMUNITY RENEWAL \& ITS RELATIONSHIP WITH COMMUNITY GARDEN}

Community renewal is transforming communities by empowering and engaging them in various community activities (Anon., n.d.). According to the Martin Wood in 2002, 'social cohesion' and 'social capital' are the main contexts of community renewal. Social capital is all the features of social organization, such as neighborhood connection, social trust, togetherness, volunteerism, everyday sociability that facilitate coordination and cooperation for mutual benefit (Putman, 1993). Further, social cohesion is the process of social integration which mainly driven through keeping bonds and sharing moral of the community (Larsen, 2013). As an overall, community renewal; social cohesion and social capital collectively leads a social inclusion to make mutual benefits for each other. However, when it comings to discussed on the relationship among community garden and community renewal, already scholars has demonstrated that community garden as an innovative method for renewal city population (Hynes, 1996) because which build strength and capacity among community (UKY, 2004), increase sense of belongingness (Samuels, 2004), community spirit and fellowship felt within a group (Lee, 2009). However, as it name implies, community garden is a collective venture that entails the formation of social network (Jamison, 1985) while renewing city neighborhoods (Gulas, 2014).

There are several investigations has done in the context to identify the relationship between community garden and community renewal. In that case, most of the scholars have pointed out that two terms named community interaction and community involvement under the broader theme of community renewal. Because, community interaction (collective activities, socializing, and belonging to community) is foster norms of reciprocity and trust conventional forms of social capital (Putnam, 2000) among members of the community garden. As well, community interaction is often referred as a key criterion to assess social capital in community gardens (Nicole Rogge, Insa Theesfeld and Carola Strassner , 2018). In addition, the gardens are venues for active citizen participation (Jamison, 1985) which also central to social capital. According to the Teigetal in 2009, "community gardens provide opportunities to build civic engagement and a sense of collective efficacy to take action for the common good of the neighborhood". Moreover, according to the Shanon C. Kearney in 2014, involvement of local residents is needed to function a community garden and to renewal community. However, as an overall, community interaction and community involvement are the perceived criteria scholars have used to define and measure diverse degrees of community renewal (Nicole Rogge, Insa Theesfeld and Carola Strassner , 2018).

In the context Shanon C. Kearney in 2014 has used twenty different factors under three categories as site aesthetics, social connectedness and youth empowerment to investigate the community involvement and community interaction incorporating with the social capital theory. In order to, they had used the factors such as togetherness, community support, sense of belonging, loyalty, desire, income, proximity to community garden, skill Building, interaction with friends, happiness, land scaresity etc. As well, Andreas Wesener in 2020 has done a research investigation in New Zealand and Germany to identify the factors in relation to community renewal incorporating with the place making theory (Appendix 4). These all scholars in their research investigations have tried to emphasize the reinforcement of community garden to buildup community interaction and involvement by finding and evaluating these factors. In that case they have used a functioning community garden because these factors cannot identify in a mal functioning garden.

\subsection{THEORIES FOCUS ON COMMUNITY RENEWAL}

\subsubsection{Place making theory}

Place making is the process which transforms inhabits places into living places for socializing and interaction with meaningful characteristics (PPS, 2007). Literature emphasizes that, four relevant aspects of place making theory which are linking to the community garden concept such as construction of (individual and collective) meaning, social exchange, social (collective and collaborative) action, and civic empowerment (Toolis, 2017). And further, has identified three different dimensions relevant to the place making theory as biophysical and technical, socio-cultural-economic and political and administrative which has used for assess the reinforcement of community garden for buildup community interaction and community involvement. Recently, place making theory is incorporates with green space planning with functional uses (Chillers, 2014). In the context, community garden has identified as invaluable platforms to observe the phenomena of space to place transformation, as reflecting community and cultural values as well as public aspirations (Wesener, 2020).

\subsubsection{Social Capital theory}


The social capital theory simply explains the co-ordination and co-operation of collective actions of participants for mutual benefits or in other words it makes possible to achieve certain aims that cannot be achieved by individuals in its absence (Putnam, 2000). This theory is talking on levels of trust, togetherness and networking, community involvement, volunteerism, generalized norms so on. According to the Troy D. Glover social capital is obtained by virtue of membership in different social structures (Portes, 1998), its maintenance and reproduction are made possible only through the social interactions of members and the continued via social relationships.

\section{The Method}

As explicated in previous to fill in the research gap selected a case study which situated in Pepiliyana east GND in Kesbewa DSD of Colombo district and the area has spread over four-acre land.

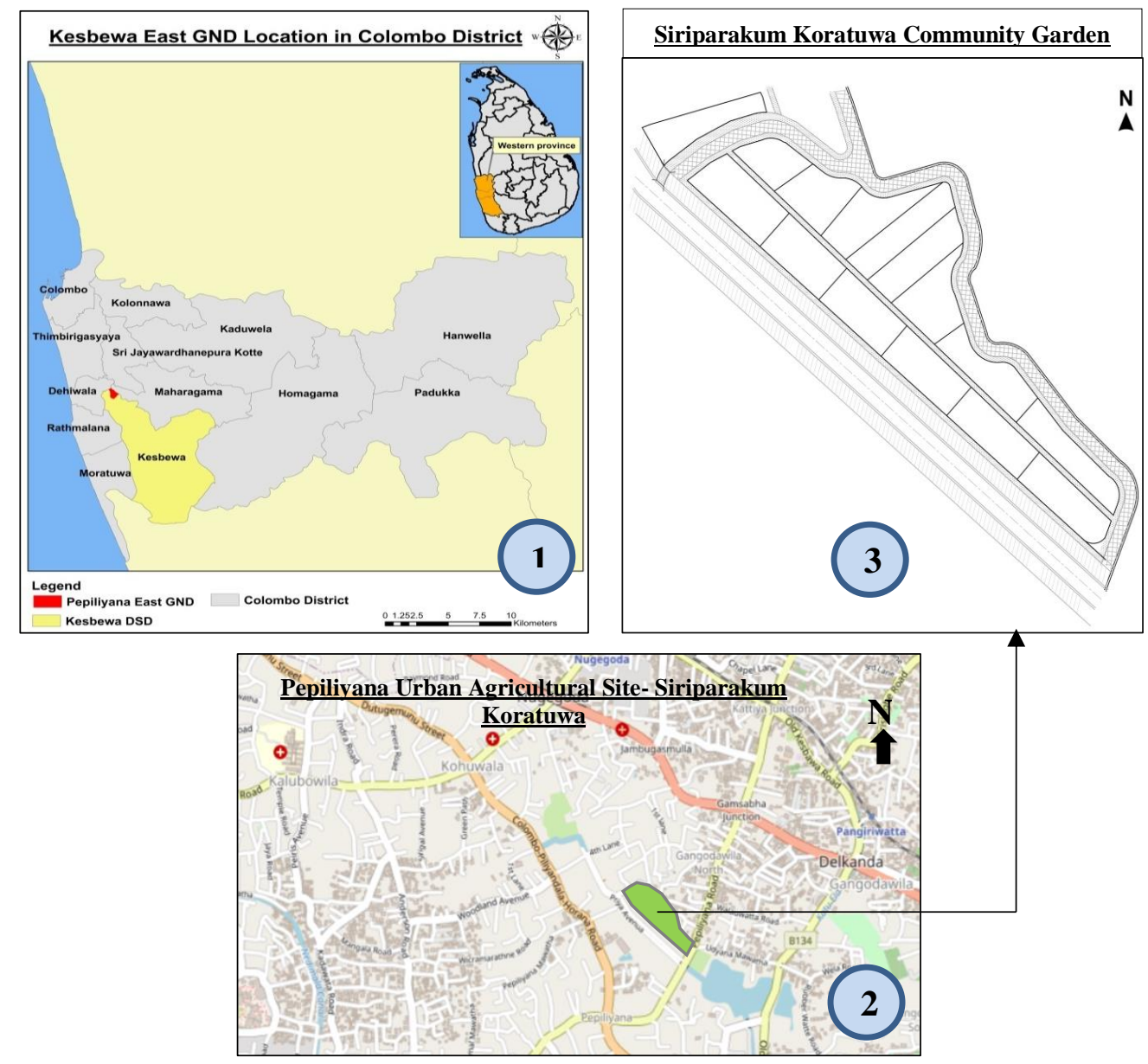

Figure 1, Location map of Siriparakum Koratuwa community garden (Source: Sri Lanka Land Development Corporation)

In order to select this functioning case study, followed the literature base variables as systematic way. Sarah Taylor Lovell in 2010 has presented some variables which need to function an urban agriculture site. Using these key variables selected the suitable site for carrying the research study. Further, this community garden has been chosen after doing an informal discussion with Sri Lanka Land Development Corporation regarding the accessibility for data collection.

\begin{tabular}{|l|l|}
\hline \multicolumn{1}{|c|}{ Function } & \multicolumn{1}{c|}{ Description and Justification } \\
\hline Production & $\begin{array}{l}\text { Urban agriculture produces fruits, vegetables and medicinal } \\
\text { plants. }\end{array}$ \\
\hline Waste management & $\begin{array}{l}\text { Organic waste products can be composted and used as a fertility } \\
\text { resource for growing food products. }\end{array}$ \\
\hline Bio diversity & $\begin{array}{l}\text { Agricultural systems can support a wide range of species, } \\
\text { including some native plants. }\end{array}$ \\
\hline
\end{tabular}




\begin{tabular}{|l|l|}
\hline Urban greening & $\begin{array}{l}\text { Community gardens contribute to the greening of urban areas } \\
\text { improving aesthetics beauty. }\end{array}$ \\
\hline Energy conservation & $\begin{array}{l}\text { Producing food locally and reduces the embodied energy } \\
\text { resulting from inputs, transport, and packaging. }\end{array}$ \\
\hline Micro climate control & $\begin{array}{l}\text { Urban agriculture can positively alter microclimate through } \\
\text { controlling humidity, protecting wind pattern and shade. }\end{array}$ \\
\hline Education & $\begin{array}{l}\text { Learn about foods, nutrition, cooking, growing, nature, } \\
\text { economics, and cultures through urban agriculture. }\end{array}$ \\
\hline Community based & $\begin{array}{l}\text { Community participation, motivation among each other to } \\
\text { achieve collective goals. }\end{array}$ \\
\hline
\end{tabular}

Table 1: Case study selection variable and description

(Source: (Lovell, 2010)

To find a suitable functioning location for the research purpose I used "weighted scoring method" in a systematic procedure. The weights for each criterion were put according to the level of significance of availability of variables in the community garden as understood from the literature reviews. Eventually, out of the five community garden sites named Halgahakumbura, Eli house park, Dematagoda Ayurvedic site, Sanstha Koratuwa and Siriparakum Koratuwa, selected the Siriparakum Koratuwa case study which was the ranking levels 2 in weighted scoring method. The main reason for selecting this ranking level 2 garden is availability of every variable within the garden context which explained by Taylor Lovell that needs for a better function, when comparing with other gardens in Colombo district. Because according to the scholars cannot to assess the reinforcement of community garden to renewal community within a malfunctioning garden. As the responsible institution for this site, Sri Lanka Land Development Corporation (SLLDC) is collecting waste from the peripheral areas of Colombo and daily produce 35-ton compost. And then those carbonic fertilizers they use for this garden to grow vegetables like tomato, okra, capsicum, cabbage, spinach, splinter, chili, brinjal, sweet potato, cucumber etc. Moreover, 72 households are participating continuously to this garden for gardening purpose, buying carbonic foods, spent time leisurely and for education purposes. Specially, within the garden has a small boutique to sell its production for the surrounding people. Hence, there has not been happen any energy deterioration for transportation or packaging. In further, as I feel this garden is contributes to control the micro climate and nurture bio diversity and urban greening while adding an aesthetic beauty to the urban setting. However, every variable that derived from Lovell's explanation were available in the Pepiliyana Agricultural site and that was the rational of selection this case study.

Moreover, to examine the reinforcement of community garden for buildup community interaction and community involvement primary data collected through in-depth interviews and on-site observations. In the study, in-depth interviews used to find grass root level pushing as well attractive, social and physical motivational factors. In that case, questioned on the reasons for participating to this garden instead of using their home garden, benefits people can be obtained from garden, pre and post experience of community with garden and the way it affected to change their life style, future expectations regarding community garden aligning with the factors coming under the three dimensions of place making theory to assess the reinforcement of community garden for build community interaction and involvement. Meanwhile, on site observation used to identify and verify the interviewed data through real ground observation. Parallelly, the data collection is done using the random sampling method and selected sample size was 18 households. Because as scholars are mentioning $10 \%$ samples out of the total population is enough for the in-depth interviews and further in reviewed literatures, researchers have only limited to the 15 to 20 sample sizes. Accordingly, most of the researches has used 20 to 40 minutes per person for interview and with that sense I interviewed each person in 30 minutes.

\begin{tabular}{|c|c|c|c|}
\hline Site name & Total household & Sample quantity & Percentage \\
\hline Siriparakum Koratuwa CG & 72 & 18 & $25 \%$ \\
\hline
\end{tabular}

Table 2: Sample size

(Source: Compiled by author)

Furthermore, the data was qualitatively analyzed through narrative analysis, Text search query analysis, word cloud frequency analysis and hierarchical chart analysis using NVvio software. 


\section{Analysis \& Findings}

To analyze the research question of what are the social and physical factors that influenced to motivate community to community garden, followed the thematic analysis in NVvio software. In that case, the collected data and stories through in-depth interviews were coded under broader themes. In first, the word cloud frequency analysis carried out in relation to the research question. As elaborated in the literature high quantity of respondents highlighted land, togetherness, happiness, time, friends, knowledge, desire, and income as the main social and physical factors which has influenced for their motivation.

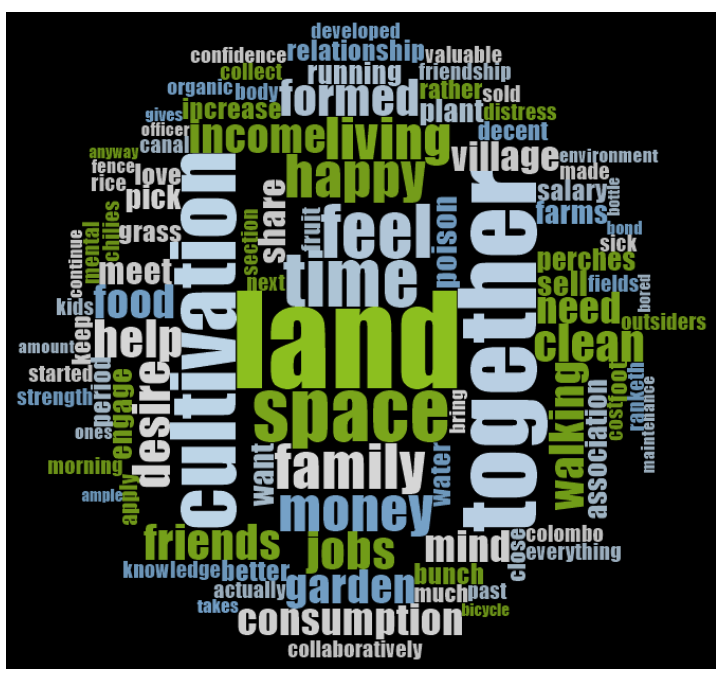

Figure 2, Word frequency analysis (Source: Compiled by author)

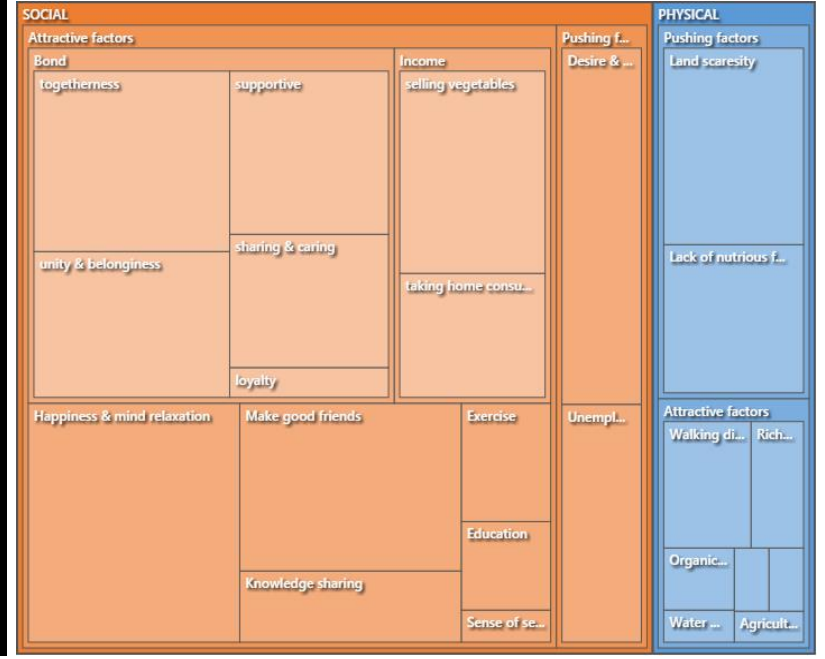

Figure 3, Hierarchical chart analysis (Source: Compiled by author)

Then the identified social and physical factors through word cloud frequency analysis under different broader themes were further coded aligning with the knowledge obtain from literatures as showing in hierarchy chart analysis. In that case, the attractive factors mostly indicate the benefits and convenience that people having due to community garden and the pushing factors indicate the grassroots level problems which had people to attracting to this garden. According to that, this chart has identified 15 different social factors as togetherness, supportiveness, unity and belonginess, sharing and caring, loyalty, happiness and mind relaxation, make good friends, sharing knowledge, selling vegetables, taking vegetable for home consumption, exercise, education, sense of security, unemployment, desire and experience. As well there are 9 different physical factors also were derived from community stories such as land scaresity, lack of nutrias foods, walking distance, rich yield, organic fertilizer, equipment, agricultural edification, water provisioning and crops variety. Most of the identified factors were derived incorporating with the three dimension of place making theory.

In next sections, the identified each factor will be discussed further and those factors will be proved by using quotes which emerged from the participant's stories.

\subsection{SOCIAL FACTORS}

Out of the total respondents most of them have mentioned that the ability of garden has to uplift the social relationships and ties as the main factor for participating to this garden. Under this broader theme identified five different sub factors as togetherness, unity and belonginess, sharing and caring, supportiveness and loyalty. According to hierarchy chart analysis a larger portion has gone for togetherness, because out of the total respondents all of them have mentioned that this as the place where people can interact together with each other.

"We are doing a new rice festival and giving large alms for monks at this threshing floor in annually. It is a beautiful sight. We prepared the curries from the vegetables picked from our garden. Everyone on the crofts provided many vegetables and chilies as they could" (respondent 5) 
And also, the mutual togetherness between people who are working in this garden is very high. Because of that they have already established a community-based organization to share the mutual benefits for everyone when they are in any spiny situation.

"We formed an association for this garden called Ranketh. We have an account also and collecting Rs. 50 per month from all the members who work in our garden. Without such kind of bond, we cannot do this successfully" (Respondent 5)

According to the interviewed communities' perception the garden is not only supported to uplift the togetherness among the gardeners and neighbors, but also it has helped to increase the togetherness among family members also.

"Most of the time our family comes together. During Corona period we were on the garden throughout the day because we are very lazy to stay at home. Even we missed our family in our homes we are getting together in here" (Respondent 9)

And also, under the theme of bond the next highly allocated portion of attractive factor is unity and belonginess. As community expressed, they are very lazy to engage with cultivation at home because they are alone. But here they nothing feels any isolation because they feel that they are belonging to a larger portion of community.

"If someone works in one part and another person works in another part, we have a great strength. Not like working alone at ours homes. We are not lazy if we hear a voice. When I finish works in my part, I go to the other's part and talk for a while with them. Then we do not feel a loneliness" (Respondent 10)

And moreover, out of the total respondents 12 has mentioned that the unity between each other has expanded more and more due to involving to this garden.

"We have been running this farm since 7 years now and we have not heard anything about any attacks. That means no disputes. That is the thing what we want to see. At least we don't have used the fence to demarcate boundaries of our crofts" (Respondent 5)

According to the thematic analysis, out of the total 18 respondents 11 and 9 has respectively mentioned that the main reason for engaging with this garden as supportiveness and sharing \& caring among the community because everyone who is working in here is well lovely and well corporative. They share the vegetables, plants, seeds and foods what they have with each other.

"If I want to buy a vegetable which is not grown at my croft, I ask the people working on the other adjoining land. There is an exchange between us and it is a good relationship. They give us our lost vegetables and we give them vegetables they don't have. And also, we share the foods that we bring to the garden" (Respondent 10)

"Even if someone suddenly gets sick, there is nothing to be afraid because all of us are very much supportive. Actually, we are in together when someone in distress at any time" (Respondent 6)

Apart from that, due to this supportiveness and sharing \& caring people get some advantages also. As they expressed, there are some worse days people cannot stay whole day at their crofts. But they know that their cultivations are safe because everyone take care on others crofts as well.

"It is not the garden users but the drug lords in surrounding area who smuggle what we have grown. So, if we are not working in our croft, the people who are working in the adjoining crofts take a look at our section too. Because if there is someone on the other side, even thieves will not come" (Respondent 14)

As well these crofts have been helped to community to grow their loyalty among people rather engaging with cultivations at their homes individually.

"The people who are working on this garden are very loyal. Even if someone is not in their lands other peoples are not going to their lands at least to pick some vegetables. We are trusting each other" (Respondent 6) 
In next, the mostly highlighted social factor for community participation is ability to earn an income. According to the thematic analysis 13 peoples have directly find income by selling vegetables and 8 peoples earn income indirectly by taking vegetables for their home consumption. Most of the people who have engaged with this garden are labors and they do not have a permanent job or a salary. But this garden has become an invaluable place for them to make some money additionally and to keep their economy stably.

"If we have a good harvest, we can find a really good income. Anyway, I sold at least 5 bunches of greener leaves for a day and find the daily cost. Actually, I earning 500 to 1000 rupees per day and at the end of the month we can get a lot income" (Respondent 8)

Parallelly, most of the garden users have not bought vegetables from the market since 6 to 7 years because they take vegetables for their consumption from the Siriparakum Koratuwa garden. Through that they save some money which cost for buy vegetables from market. That is how they earn income.

"I take foods need for my home is from here. Then the cost will be cheaper for us to buy vegetables from market" (Respondent 3)

Beside all above factors 13 ones out of the total are attracting here due to their mental complacencies because these crofts are a pleasure for their monotonous life style spending at highly populated Colombo district.

"I am now retired and coming here is good for my mind because I do not feel time passing in here. It is a great consolation to my heart. In the morning I see the fruit of grown things and then feel amazingly happy" (Respondent 7)

"We are living with the lot of problems. Ample of economic problems we have. When we go there, we forget all those problems and our minds are relaxing. And the happiness we feel by looking at the cultivation cannot be taken for money" (Respondent 9)

Apart from that, some participating people are happing from their inside, because they are getting a spiritual cure from the garden while feeding animals by taking vegetables from their garden.

"These sweet potato leaves are not for me to eat. There is a rabbit in the house next to us. These all are for that rabbit. I cannot express that feeling and it is weird mental cure" (Respondent 12)

As such the other most important social factor which has supported to build up community interaction and involvement is ability to make new good friends. According to the thematic analysis 14 respondents has mentioned that clearly. Without any age differences all of the elders, youngers and children have added some good friends for their lives through the participation of garden.

"Rather than before, the number of friendly people has increased now. Even in Colombo, this is very valuable for maintaining friendships like in a village" (Respondent 1)

According to the observation these communities are very happily and well mutually work with their friends in the crofts rather staying at their homes lonely.

"I come here definitely to work with my friends because it is so funny. When I come here, I bring a bottle of tea and some foods for all. So, we sit, eat and work together and have a fun here" (Respondent 5)

More than that identified, three different social attractive factors. In that case, out of the total respondents respectively 6, 4 and 3 have mentioned that ability to share knowledge on agriculture between each other, ability to get exercise for continuing a good health and ability to extract education and lessons on environment as the main reasons for their participation to these crofts. And also, these three social factors are the identified least affected factors for renewal community.

"As an individual we do not have such a big knowledge to do gardening work well at our homes. Here we share the knowledge that we know about the crops with each other" (Respondent 9)

"We both are older people and if we do not engage with any work our body will be crippled. As this way if we work at least two hours, it is good for our body as well our mind" (Respondent 13: older couple) 
"This garden provides a good education for our children. Otherwise, when they get stuck with their school works, they will miss what the environment is says" (Respondent 9)

Apart from the social attractive factors derived two social pushing factors which motivated community to Siriparakum Koratuwa garden. Out of the total respondents 12 ones are said that they are more preferred to participate here because they already having past experience on doing cultivation. Specially, until happens the urban agricultural land filtration with urban sprawl they have engaged with cultivation and therefore, these peoples are concerning this garden as a gift that they received.

"We have a good habit of weeding and earlier we done 2 acres of paddy lands. Therefore, we never give up doing cultivation in here because we know the taste of rice and vegetables" (Respondent 8)

"My village is Bandarawela. When I was there, this is the work I did. I really have that desire to do cultivation after settle down in Colombo also. That is why definitely I come here" (Respondent 4)

And also interviewed communities expressed that, they have the desire to continue doing cultivation in further although how much they feel the difficulties.

"When I go home after working in the garden, I feel that I do not have my backbone. The limbs are hurting. But it is a crazy to be garden in next morning too. Actually, how much we work hard in the morning and the evening to grow these plants properly (sighing). We are waiting until come out a flower or a fruit from a tree" (Respondent 15)

As such, the last social pushing factor which influenced for the community participation is unemployment. More than $90 \%$ of the garden users do not having a permanent job or a salary and their economy is very unstable.

"I am just at the home because I do not have a job to do. During the Corona period I lost my job. Since the same time, I came here" (Respondent 13)

\subsection{PHYSICAL FACTORS}

As focus in the research question derived 9 different physical factors to evaluate the reinforcement of community garden to renewal community and now moving to its deep explanation.

According to the observation the people who are living around Colombo cannot cultivate as they wish with the issue of land scaresity. Even most of them do not having minimum plot coverage not for the gardening at least to make their houses. More than 50\% respondents are living in a rented house. As well all of the participants who are joining with this garden are living in a concrete yard and no much integration with nature. Out of the total respondents 12 peoples have highlighted this issue as the main pushing reason for their participation to this garden.

"I live in Kirulapana. My land is 2 perches. No space to cultivate. There is only my small house. On the way out of the house is road" (Respondent 3 )

According to the thematic analysis the secondly highlighted highest pushing physical factor is inability to access for nutrias foods \& food insecurity. Out of the 18 respondents half of people are attracting to this garden due to this issue when going to buy foods from market. They are very confidently saying that this is the place where they can pluck vegetables without any poisons because they are not fake to themselves.

"Here we can eat the foods without any poison and stay healthy without getting sick. Even, a bunch of leaves also a five hundred percent sure because we made this" (Respondent 5)

"From here, we can confidently get the things what we need to eat and drink. We are not fear to cook these vegetables for our children because we are using carbonic fertilizers" (Respondent 10)

Furthermore, according to the hierarchy chart analysis the highest portion under physical attractive factors has been allocated for the walking distance because lots of people who are using this garden have settled down within $500 \mathrm{~m}-1 \mathrm{~km}$ buffer zone. Therefore, they are much love to daily travel to this place by foots or using foot cycles. 
"We are most prefer to go there due to the walking distance. If this garden had been a little far away from our homes we would not have gone" (Respondent 15)

In next, factors of ability to pluck a rich yield and usage of organic fertilizers have become into a reason for community participation to the garden. As peoples are saying, SLLDC are giving compost in free of charge which need for their crops and it has become a big alleviation for them to continue their cultivations successfully.

"I put all the thrown grasses in here and waste generating in our home to the compost bucket at the garden croft and when the garbage is composted, it is taken and put into the vegetable plants additionally receiving fertilizers from SLLDC." (Respondent 15)

Moreover, in this garden each person has 10 perch of land and a well weather condition to grow vegetables properly. Due to that, people can pluck a rich yield from here rather doing cultivations within a limited space at home.

"There are big trees in our home and brush wood is high to grow the crops. It's so sunny here and the plants grow well. If we take a good effort, we can get a good harvest from here." (Respondent 6)

During the interviewing period water provisioning and equipment facilities have highlighted by community as the infrastructure related physical attractive factors which influenced for their participation. As community expressed, most of the people who are coming to this garden are paying a water bill for their home consumption. If they engage with cultivations at home, they have to defray an additional water cost for the cropping also. But in here they are receiving essential infrastructure facilities in free of charge as they wish.

"The government gives us all the equipment what we need to cultivate. At the beginning of this year also we got some hoes and tools to continue these cultivations in successful way" (Respondent 1)

And also, most of the garden users who are living in Colombo do not have engaged with this job in earlier and this is a new experience to them. Because of that, instructions given by the agricultural officers about cultivations are invaluable for them to attract here. In addition to that, community highlighted the crops variety that they can grow in here with the knowledge gain from officers, as another factor to participate this garden.

"At our home, we grow one or two varieties. But here we grow many varieties with the support of agricultural officers. I have grown brinjal, crushed brinjal, kathurumurunga, kirihenda, ranawara, kiriaguna, hulankiriya, kiriala etc. Everything is there. Not nothing anything" (Respondent 15)

However eventually, all the factors reviewed under three dimensions of place making theory as well other literatures which used to assess the reinforcement of CG for buildup community interaction and community involvement were found from the community stories in related to the selected case study. Hence, eventually there is a reinforcement of Siriparakum Koratuwa CG to renewal community.

\section{Conclusion \& Recommendation}

This study is attempts to assess the reinforcement of community garden for renewal community by investigating the different social and physical factors which are influencing to motivate community to community garden. However, community renewal is a broader theme and from that selected only two terms as community interaction and community involvement with the help of literatures. In context scholars has used factors coming under three dimensions of place making theory as well other literatures, to assess the reinforcement of CGs to make community interaction and community involvement. And according to them these factors can be identify only within a functioning garden. Therefore, using the variables which presented by Sarah Taylor Lovell in 2010, selected a functioning CG to undertake the research investigation further. Eventually, all the factors scholars used in their own contexts which need to assess the reinforcement of community garden for renewal community were found in the selected case study also. Hence, as this study is aiming collectively 24 social and physical factors are driven to prove the community gardens specially around Colombo district has a reinforcement to renewal community. However, in the research has selected only one case study area and because difficult to generalize the findings and validation of the findings will be less. Therefore, further investigations are needed to get findings on the same research question considering more than one case study areas to generalize the findings. Because although Siriparakum Koratuwa garden contained the social and physical factors which 
derived from literatures that affect to uplift the community interaction and community involvement, it may be differ from context to context based on the different urban characters like less urban densification, sociodemographic characteristics so on.

\section{References}

Alberto Zezza , Luca Tasciotti, 2010. Urban agriculture, poverty, and food security: Empirical evidence from a sample of developing countries. ELSEVIER, pp. 1-9.

Aleksandra Dukic, Tijana M. Vujicic, Branislav Antonic, 2018. Greening as an Approach for Urban Renewal of Shrinking Cities. ResearchGate, pp. 1-12.

Andre Viljoen \& Katrin Bohn, 2009. Continuous Productive Urban Landscape (CPUL):Essential Infrastructure and Edible Ornament. pp. 1-12.

Andreas Wesener, Runrid Fox-Kämper , Martin Sondermann and Daniel Münderlein, 2020. Placemaking in Action: Factors That Support or Obstruct the Development of Urban Community Gardens. MDPI, pp. 1-29.

Arnberger, A., 2012. Urban Densification and Recreational Quality of Public Urban Green Spaces-A Viennese Case Study. OPEN ACCESS sustainability, pp. 1-18.

Authority, U. D. \& developement, M. o. M. a. w., 2018. City of Colombo development plan. pp. 1-107.

BarBara Maćkiewicz, raúl Puente asuero, krystyna Pawlak, 2018. Reclaiming Urban Space: A study of community gardens in poznań. de gruyter open, pp. 1-20.

Bende Csaba; Nagy Gyula, 2017. effects of Community gardens on local Society: The Case of Two Community Gardens in Szeged. pp. 1-18.

Berkman, 2015.

Chithrangani WM Rathnayake, Simon Jones and Mariela Soto-Berelov , 2020. Mapping Land Cover Change over a 25-Year Period (1993-2018) in Sri Lanka Using Landsat Time-Series. MDPI, pp. 1-19.

D. K. N. G. Pushpakumara, B. Marambe, G. L. L. P. Silva, J. Weerahewa,B. V. R. Punyawardena, 2012. A REVIEW OF RESEARCH ON Homegardens in Sri lanka: the status, importance and future perspective. pp. 172.

Drescher, A., 2001. The integration of Urban Agriculture into urban planning - An analysis of the current status and constraints. pp. 1-12.

Francesco Orsini \& Remi Kahane \& Remi Nono-Womdim \& Giorgio Gianquinto, 2013. Urban agriculture in the developing world: a review. INRA springer, pp. 1-26.

Galdini, R., 2016. RETRACTED ARTICLE: Placemaking as an approach for innovative urban renewal practices: community gardens in Berlin. Routledge, pp. 1-22.

Glover, T., 2004. Social capital in the lived experiences of community gardeners. Leisure Sciences, p. 143162.

Glover, T. D., Parry, D. C. \& Shinew, K. J., 2004. Leisure Space as a Potential Site for Interratial Interaction:Community Garden in Urban Areas. Journal of Leisure Research, September.pp. 1-21.

Harris, E., October 2008 . Urban Planning for Community Gardens: What has been done overseas, and what can we do in South Australia?. s.l.:s.n.

Hou, J., 2017. Urban Community Gardens as Multimodal Social Spaces. pp. 1-19.

Hubert De Bon, Laurent Parrot, Paule Moustier, 2008. Sustainable urban agriculture in developing countries. A review. Agronomy for sustainable development, pp. 1-12.

In Kwon Parka and Patricia Cioricib , n.d. Determinants of vacant lot conversion into community gardens: Evidence from Philadelphia. International Journal of Urban Sciences.

In Kwon Parka and Patricia Cioricib, D. o. U. A. U. o. S. S. K. \& Department of Public Policy and Administration,

Ingamells, A., 2006. Community development and community renewal: tracing the workings of power. Community Development Journal, pp. 1-14.

Institute, I. w. m., 2013. Urban agriculture gets policy-level support in Sri Lanka's Western Province.

Jae Ho Lee and David Matarrita-Cascante, 2019. Gardeners' Past Gardening Experience and Its Moderating Effect on Community Garden Participation. MDPI sustainability, pp. 1-16.

Kearney, S. C., 2014. The Community Garden as a Tool for Community Empowerment: A Study of Community Gardens in Hampden County. s.l.:s.n.

Lovell, S. T., 2010. Multifunctional Urban Agriculture for Sustainable Land Use Planning in the United States. OPEN ACCESS sustainability, pp. 1-24.

Mary L. Ohmer, Pamela Meadowcroft, Kate Freed \& Ericka Lewis, 24 Nov 2009. Community Gardening and Community Development: Individual, Social and Community Benefits of a Community Conservation Program. Journal of Community Practice, pp. 1-24.

Melissa N. Poulsen, K. R. S. H. C. A. G. H. P. S. L. D. R. K. W. a. P. J. W., n.d. Growing an Urban Oasis: A 
Qualitative Study of the Perceived Benefits of Community Gardening in Baltimore, Maryland. The Journal of Culture \& Agriculture, pp. 1-14.

Na Ra Jeong, K. J. K. H. G. Y. S. W. H. a. S. Y. A. D. N. I. o. H. \&. H. S., 2019. The Perception of Urban Residents on Creation and Management of Community Gardens. J. People Plants Environ., wang Jin .pp. 1-14.

NadaPetrovica,TroySimpsona, BenOrloveb, BrianDowd-Uribec , 2018 Octomber. Environmental and social dimensions of community gardens in East Harlem. Elsevier, pp. 1-14.

Nicole Rogge, Insa Theesfeld and Carola Strassner, 2018. Social Sustainability through Social Interaction-A National Survey on Community Gardens in Germany. MDPI sustainability, pp. 1-18.

Ogenis Brilhante and Jannes Klaas , 2018. Green City Concept and a Method to Measure Green City Performance over Time Applied to Fifty Cities Globally: Influence of GDP, Population Size and Energy Efficiency. MDPI sustainability, pp. 1-23.

PUSSELLA, P. G. R. N. I., 2017. Is Colombo city, Sri Lanka secured for urban green space standards?. pp. 111.

Susantha Amarawickrama, P Singhapathirana and N Rajapaksha, 2015. Defining Urban Sprawl in the Sri Lankan Context: With Special Reference to the Colombo Metropolitan Region. Journal of Asian and African Studies, pp. 1-26.

Thushara Samaratunga, Daniel O'Hare, 2013. High Density High Rise Vertical Living for Low Income People in Colombo, Sri Lanka: Learning from Pruitt-Igoe. pp. 1-7.

Torjman, S., January 2004. Community Renewal. s.l.:The Caledon Institute of Social Policy.

Travis J. Grosser, Stephen P Borgatti, 2013. Network Theory / Social Network Analysis. SAGE REFERENCE, pp. 1-8.

Wood, M., 2002. Resident participation, Social cohesion and Sustainability in Community Renewal. pp. 116.

Young, 1996.

Zeunert, J., 2018. Dimensions of Urban Agriculture. ResearchGate, pp. 1-26. 